\title{
Tissue Hypoxia: Implications for the Respiratory Clinician
}

\author{
Neil R MacIntyre MD FAARC
}

\author{
Introduction \\ Causes of Hypoxia \\ Hypoxemia \\ Oxygen Delivery \\ Oxygen Extraction/Utilization \\ Compensatory Mechanisms for Hypoxia \\ Current and Future Clinical Implications \\ Summary
}

\begin{abstract}
Oxygen is essential for normal aerobic metabolism in mammals. Hypoxia is the presence of lower than normal oxygen content and pressure in the cell. Causes of hypoxia include hypoxemia (low blood oxygen content and pressure), impaired oxygen delivery, and impaired cellular oxygen uptake/utilization. Many compensatory mechanisms exist at the global, regional, and cellular levels to allow cells to function in a hypoxic environment. Clinical management of tissue hypoxia usually focuses on global hypoxemia and oxygen delivery. As we move into the future, the clinical focus needs to change to assessing and managing mission-critical regional hypoxia to avoid unnecessary and potential toxic global strategies. We also need to focus on understanding and better harnessing the body's own adaptive mechanisms to hypoxia. Key words: hypoxia; hypoxemia; alveolar ventilation; ventilation/perfusion matching; diffusion; hemoglobin binding; hemoglobin-oxygen binding; regional oxygenation; oxygen extraction; oxygen utilization; hypoxia-inducible factors. [Respir Care 2014;59(10):1590-1596. ㅇ 2014 Daedalus Enterprises]
\end{abstract}

\section{Introduction}

Oxygen is essential for normal aerobic metabolism in mammals. ${ }^{1-3}$ The key reaction occurs in the mitochondria of cells and involves combining a fuel (eg, sugars, fats)

\footnotetext{
Dr MacIntyre is affiliated with the Division of Pulmonary and Critical Care Medicine, Duke University Medical Center, Durham, North Carolina.

Dr MacIntyre presented a version of this paper at the 29th New Horizons Symposium at the AARC Congress 2013, held November 16-19, 2013, in Anaheim, California.
}

The author has disclosed no conflict of interest.

Correspondence: Neil R MacIntyre MD FAARC, E-mail: neil.macintyre @ duke.edu.

DOI: $10.4187 /$ respcare. 03357 with oxygen to produce energy (converting adenosine $5^{\prime}$ diphosphate to adenosine $5^{\prime}$-triphosphate) along with $\mathrm{CO}_{2}$ and $\mathrm{H}_{2} \mathrm{O}$. Hypoxia is a state of low oxygen content and partial pressure in the cell. Depending upon the cell type, its metabolic demands, and its ability to adapt to hypoxia, the response to various levels of hypoxia can range from substantial adaptation to cell death. ${ }^{4,5}$ The discussion below will focus on 3 areas: (1) causes of hypoxia, (2) physiologic responses/adaptations to hypoxia (global, regional, and cellular), and (3) current and future clinical implications.

\section{Causes of Hypoxia}

Tissue hypoxia can be caused by one of 3 general abnormalities: hypoxemia, impaired oxygen delivery to tissues, and impaired tissue oxygen extraction/utilization. Each will be addressed separately. 


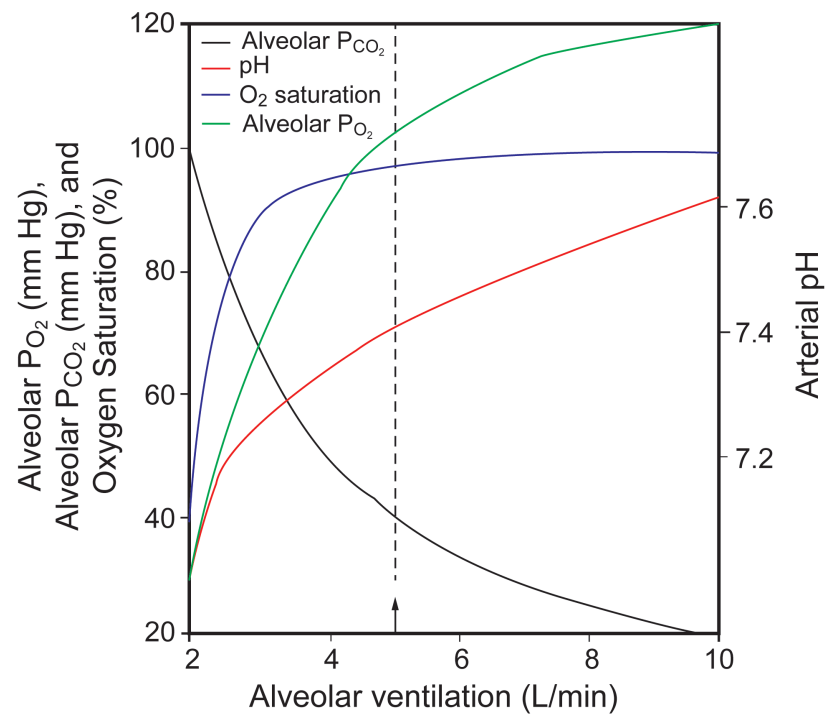

Fig. 1. Plots of alveolar $\mathrm{P}_{\mathrm{O}_{2}}$, hemoglobin saturation, and alveolar $\mathrm{P}_{\mathrm{CO}_{2}}$ as a function of alveolar ventilation in a normal subject at sea level (inspired oxygen pressure of $150 \mathrm{~mm} \mathrm{Hg}$ ). The dashed line indicates normal values. Adapted from Reference 2.

\section{Hypoxemia}

Hypoxemia refers to low oxygen content in arterial blood, and there are several factors that impact this state. ${ }^{1-3}$ The first is the oxygen content of inspired gas. At sea level, the inspired $\mathrm{P}_{\mathrm{O}_{2}}$ is $\sim 150 \mathrm{~mm} \mathrm{Hg}$. Inspired $\mathrm{P}_{\mathrm{O}_{2}}$ falls progressively with altitude and nadirs at $43 \mathrm{~mm} \mathrm{Hg}$ at the summit of Mt Everest (29,028 feet).

Alveolar ventilation is the next step in oxygenating blood. As alveolar ventilation increases, alveolar $\mathrm{P}_{\mathrm{O}_{2}}\left(\mathrm{P}_{\mathrm{AO}_{2}}\right)$ rises logarithmically and assymptotes on the inspired $\mathrm{P}_{\mathrm{O}_{2}}$ (Fig. 1). ${ }^{2}$ From Figure 1, it can be seen that in a normal human at rest with an inspired $\mathrm{P}_{\mathrm{O}_{2}}$ of $150 \mathrm{~mm} \mathrm{Hg}$, an alveolar ventilation near normal (eg, $5 \mathrm{~L} / \mathrm{min}$ ) provides a $\mathrm{P}_{\mathrm{AO}_{2}}$ of $100 \mathrm{~mm} \mathrm{Hg}$, a pressure adequate to fully saturate hemoglobin $(\mathrm{Hb})$. Importantly, because oxygen is poorly soluble in plasma, once $\mathrm{Hb}$ is fully saturated, increasing alveolar ventilation further adds little to blood oxygen content (Fig. 1). This is in contrast to $\mathrm{P}_{\mathrm{CO}_{2}}$, which continues to decrease in both blood and alveolar gas as alveolar ventilation is progressively increased (Fig. 1).

Once oxygen is in the alveolar spaces, the matching of blood and alveolar gas is the next step in determining arterial oxygen content. ${ }^{1-3}$ In normal humans at both rest and exercise, smooth muscles in both the airways and blood vessels ensure that ventilation/perfusion ( $\dot{\mathrm{V} / \dot{Q})}$ is matched nearly $1: 1$ in all alveolar-capillary units. In disease states, $\dot{V} / \dot{Q}$ relationships become deranged, and oxygen transport into blood is impaired. Similar to the phenomenon described in Figure 1, because of poor $\mathrm{O}_{2}$ solubility in plasma, relative hyperventilation and $100 \% \mathrm{Hb}$ saturation

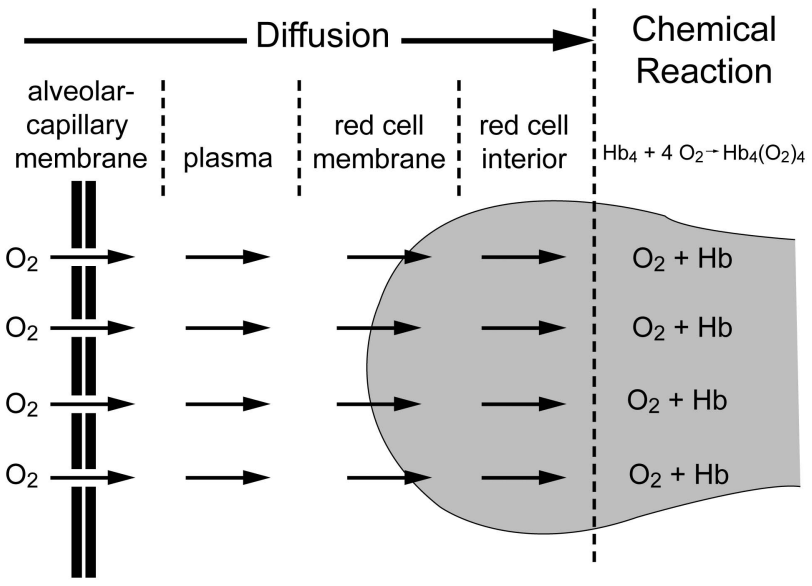

Fig. 2. Depiction of the various barriers oxygen must traverse as it moves from the alveolar space to ultimately combine with hemoglobin $(\mathrm{Hb})$ in the red blood cell. Adapted from Reference 6.

in high $\dot{\mathrm{V}} / \mathrm{Q}$ units cannot make up for the unsaturated $\mathrm{Hb}$ coming from underventilated low $\dot{V} / \mathbf{Q}$ units. This is not the case for $\mathrm{CO}_{2}$, where high $\dot{\mathrm{V}} / \dot{\mathrm{Q}}$ units can compensate for low $\dot{\mathrm{V}} / \dot{\mathrm{Q}}$ units. $\dot{\mathrm{V}} / \mathbf{Q}$ inhomogeneities thus have less effect on $\mathrm{P}_{\mathrm{CO}_{2}}$.

Regardless of $\dot{\mathrm{V}} / \dot{\mathrm{Q}}$ matching, the next step in blood oxygenation is the diffusion of oxygen through the alveolar-capillary interface and plasma and then into the red blood cell cytoplasm, where it can bind with the $\mathrm{Hb}$ molecule (Fig. 2). ${ }^{6}$ This can be expressed by the determinants for lung diffusing capacity $\left(D_{L}\right): 1 / D_{L}=1 /\left(D_{M}\right)+$ $\left(1 / \mathrm{V}_{\mathrm{c}} \times \theta\right)$, where $\mathrm{DM}$ is the membrane diffusing capacity reflecting the properties and surface areas of the alveolarcapillary interface, $\mathrm{V}_{\mathrm{c}}$ is the capillary $\mathrm{Hb}$ volume, and $\theta$ is the binding rate of $\mathrm{Hb}$ to oxygen. . $^{1-3,6}$

In normal humans, the diffusion and Hb-binding process is time-dependent, and equilibration generally occurs over $\sim 250 \mathrm{~ms}^{1-3,6}$ This is important because the normal transit time at rest for a red blood cell in the alveolar capillary is $500-750 \mathrm{~ms}$, a time adequate for complete $\mathrm{O}_{2}$ transfer. However, with extreme exercise and high pulmonary capillary blood flow, transit times may be shorter than $250 \mathrm{~ms}$ and produce hypoxemia. In disease states with abnormal alveolar-capillary structures and reduced $\mathrm{P}_{\mathrm{AO}_{2}}$, reduced membrane diffusing capacity and shorter transit times may both contribute to hypoxemia.

The final determinant of blood oxygen content is the amount of $\mathrm{Hb}$ in blood and its binding properties. ${ }^{7}$ In normal humans, $\mathrm{Hb}$ approaches full saturation at a $\mathrm{P}_{\mathrm{O}_{2}}$ of $>60-70 \mathrm{~mm} \mathrm{Hg}$. Tighter $\mathrm{Hb}$ binding to oxygen (a shift to the left in the oxyhemoglobin dissociation curve) means that lower levels of $\mathrm{P}_{\mathrm{O}_{2}}$ are associated with near-complete saturation of $\mathrm{Hb}$, and thus, tissue unloading is more difficult. Severe left shifting and functional loss of $\mathrm{Hb}$ can occur when oxygen-binding sites are impaired or blocked 


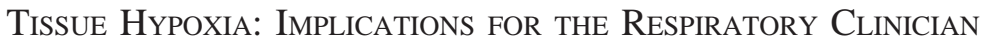

Table 1. Differences in Blood Flow, $\mathrm{O}_{2}$ Used, and Venous $\mathrm{P}_{\mathrm{O}_{2}}$ of Selected Organs and Tissues

\begin{tabular}{|c|c|c|c|c|c|c|}
\hline \multirow{2}{*}{ Tissue/Organ } & \multicolumn{2}{|c|}{ Blood Flow } & \multicolumn{2}{|c|}{$\mathrm{O}_{2}$ Used } & \multirow{2}{*}{$\begin{array}{l}\text { Arteriovenous Oxygen Difference } \\
\quad\left(\mathrm{mL} \text { of } \mathrm{O}_{2} / 100 \text { of } \mathrm{mL} \text { Blood }\right)\end{array}$} & \multirow{2}{*}{$\begin{array}{l}\text { Venous Blood } \mathrm{P}_{\mathrm{O}_{2}} \\
\quad(\mathrm{~mm} \mathrm{Hg})\end{array}$} \\
\hline & $\mathrm{mL} / \mathrm{min}$ & $\%$ of $\dot{\mathrm{Q}}_{\mathrm{T}}$ & $\mathrm{mL} / \mathrm{min}$ & $\%$ of Total & & \\
\hline Heart & 250 & 4 & 26.4 & 11 & 11.4 & 23 \\
\hline Skeletal muscle & 1,200 & 21 & 72.0 & 30 & 8.4 & 34 \\
\hline Brain & 750 & 13 & 48.0 & 20 & 6.3 & 33 \\
\hline Splanchnic (liver) & 1,400 & 24 & 60.0 & 25 & 4.1 & 43 \\
\hline Kidneys & 1,100 & 19 & 16.8 & 7 & 1.3 & 56 \\
\hline Skin & 500 & 9 & 4.8 & 2 & 1.0 & 60 \\
\hline Other & 600 & 10 & 12.0 & 5 & & \\
\hline Total & 5,800 & 100 & 240.0 & 100 & 4.1 (average) & 46 (average) \\
\hline $\begin{array}{l}\text { Modified from Reference } \\
\dot{\mathrm{Q}}_{\mathrm{T}}=\text { cardiac output }\end{array}$ & & & & & & \\
\hline
\end{tabular}

(eg, methemoglobin, sulfhemoglobin, carboxyhemoglobin). On the other hand, a shift to the right of the curve means that at a given $\mathrm{P}_{\mathrm{O}_{2}}$ less oxygen is bound to $\mathrm{Hb}$, and this facilitates delivery of oxygen into the tissues. Normal values for oxygen content in blood with $150 \mathrm{~g} / \mathrm{L} \mathrm{Hb}$ are $\sim 200 \mathrm{~mL} / \mathrm{L}$ of blood.

Hypoxemia can be expressed in several ways. Typically, a $\mathrm{P}_{\mathrm{aO}}$ of $60-80 \mathrm{~mm} \mathrm{Hg}$ is considered mildly hypoxemic, whereas a $\mathrm{P}_{\mathrm{aO}_{2}}$ of $<60 \mathrm{~mm} \mathrm{Hg}$ is considered hypoxemia generally sufficient to warrant an intervention. These values can be referenced to the estimated $\mathrm{P}_{\mathrm{AO}_{2}}$ (inspired oxygen pressure $-\mathrm{P}_{\mathrm{aCO}_{2}}$ /respiratory quotient) and expressed as an alveolar-arterial oxygen difference $\left(\mathrm{P}_{(\mathrm{A}-\mathrm{a}) \mathrm{O}_{2}}\right)$. This separates the effects of inspired oxygen pressure and alveolar ventilation $\left(\mathrm{P}_{\mathrm{AO}_{2}}\right)$ from the effects of alveolar-capillary gas transport $\left(\mathrm{P}_{(\mathrm{A}-\mathrm{a}) \mathrm{O}_{2}}\right)$ on hypoxemia. A normal $\mathrm{P}_{(\mathrm{A}-\mathrm{a}) \mathrm{O}_{2}}$ is a value less than one half your age, with a maximum of $25 \mathrm{~mm} \mathrm{Hg}$. Hypoxemia can also be expressed using arterial oxygen content, which incorporates both $\mathrm{P}_{\mathrm{aO}_{2}}$ and $\mathrm{Hb}$ properties.

\section{Oxygen Delivery}

Oxygen delivery is the process of taking oxygenated blood from the alveolar capillaries to the tissues. Oxygen delivery depends on 2 factors: $\mathrm{O}_{2}$ content and cardiac output. Mathematically, this is expressed as: $\mathrm{D}_{\mathrm{O}_{2}}=$ $\mathrm{C}_{\mathrm{aO}} \times \dot{\mathrm{Q}}_{\mathrm{T}}$, where $\mathrm{D}_{\mathrm{O}_{2}}$ is oxygen delivery, $\mathrm{C}_{\mathrm{aO}_{2}}$ is blood $\mathrm{O}_{2}$ content, and $\dot{\mathrm{Q}}_{\mathrm{T}}$ is cardiac output.

With a normal cardiac output of $\sim 5 \mathrm{~L} / \mathrm{min}$ and $200 \mathrm{~mL}$ of $\mathrm{O}_{2} / \mathrm{L}$ of blood, this translates into a normal tissue oxygen delivery of $\sim 1000 \mathrm{~mL} / \mathrm{min}$. Importantly, cardiac output can increase severalfold both under exercise conditions and in disease states (eg, sepsis, thyroid storm), resulting in the ability to deliver $\mathrm{O}_{2}$ at 5,000$7,000 \mathrm{~mL} / \mathrm{min}$ to tissues. In other disease states, $\mathrm{O}_{2}$ delivery can be impaired by hypoxemia (low $\mathrm{P}_{\mathrm{aO}_{2}}$ and/or low $\mathrm{Hb})$ as well as low cardiac output.
Importantly, oxygen delivery is regulated by region. This facilitates oxygen delivery to regions that need it most. ${ }^{1-3,6,7}$ Table 1 gives regional distributions of blood flow (and thus $\mathrm{O}_{2}$ delivery) at rest. Under exercise conditions, blood flow to skeletal muscle can increase significantly, whereas blood flow to skin and intestines may decrease. Governing this distribution of oxygen delivery are both global factors (eg, adrenergic tone, systemic inflammatory mediators) and local factors, including local hypoxia, local cytokine production, local nitric oxide, vascular factors, and $\mathrm{Hb}$ properties. ${ }^{8-11}$

\section{Oxygen Extraction/Utilization}

Oxygen extraction/utilization is the process of moving oxygen from the $\mathrm{Hb}$ molecule into the cytoplasm of cells and ultimately into the mitochondria, where it is used for oxidative metabolism. This initially involves dissociation of $\mathrm{O}_{2}$ from $\mathrm{Hb}$ and is affected by $\mathrm{Hb}-\mathrm{O}_{2}$ affinity (left shift and right shift of the $\mathrm{Hb}-\mathrm{O}_{2}$ dissociation curve as described above). Thereafter, it is largely a diffusive process, with a substantial gradient in $\mathrm{P}_{\mathrm{O}_{2}}$ between capillary blood and mitochondria. This results in mitochondrial $\mathrm{P}_{\mathrm{O}_{2}}$ of usually $<10$ mm Hg. ${ }^{3-5}$

At rest, in the average tissue capillary bed, only $25 \%$ of the delivered oxygen content actually leaves the blood and enters the tissues (extraction ratio). ${ }^{1-3,6,7}$ This means that for every $1,000 \mathrm{~mL}$ of oxygen delivered per min, $250 \mathrm{~mL}$ is extracted by the cells, and $750 \mathrm{~mL}$ remains in the blood. Thus, normal oxygen consumption is $\sim 250 \mathrm{~mL} / \mathrm{min}$ at rest, and mixed venous oxygen saturation is $\sim 75 \%$, which correlates with a mixed venous $\mathrm{P}_{\mathrm{O}_{2}}$ of $40 \mathrm{~mm} \mathrm{Hg}$. Under exercise conditions, extraction can increase to $50 \%$ or even close to 60 or $75 \%$ in elite athletes, resulting in very low mixed venous oxygen contents. As with blood flow and oxygen delivery, oxygen extraction differs by tissue (see Table 1). 
In the mitochondria, the final step of oxygen transport occurs when oxygen is combined with a fuel to produce energy in the cytochrome electron transport system. ${ }^{1-3,12,13}$ A number of inflammatory disease states (eg, sepsis) are associated with disruptions in tissue extraction and mitochondrial utilization of oxygen. ${ }^{8,9}$ Poisons such as cyanide can also directly block oxygen utilization in the mitochondria. ${ }^{14}$ Under these conditions, mixed venous oxygen concentrations are often high.

\section{Compensatory Mechanisms for Hypoxia}

If tissue hypoxia occurs, global compensatory respiratory and cardiac mechanisms similar to those seen with exercise occur to improve oxygen delivery. Acutely, these include regional pulmonary vasoconstriction to improve $\dot{\mathrm{V}} / \mathrm{Q}$ matching, hyperventilation to improve $\mathrm{P}_{\mathrm{AO}}$, acidosisrelated right shifting of the oxyhemoglobin dissociation curve to facilitate $\mathrm{O}_{2}$ unloading, and increases in cardiac output. ${ }^{3-5}$ Over time, there is also an increase in red blood cell production, and this results in polycythemia in both subjects at altitude and in patients with chronic hypoxemia. Importantly, polycythemia can also increase blood viscosity and thus potentially impair blood flow and tissue oxygen delivery through capillaries. Indeed, subjects who adapt best to altitude dwelling have only a modest polycythemic response to hypoxemia.

Hypoxemia is also associated with an increase in red blood cell 2,3-diphosphoglycerate to facilitate $\mathrm{O}_{2}$ unloading in the tissues. ${ }^{5}$ If regional hypoxia is present (eg, regional ischemia, exercise, or inflammation), regional blood flow distributional changes also occur to direct blood flow to where oxygen delivery is needed most and away from regions that are less mission-critical. ${ }^{5}$

Regardless of the cause of hypoxia, at the cellular level, important adaptive mechanisms also exist. Central to all of these are hypoxia-inducible factors (HIFs), a group of heterodimeric proteins that interact with hundreds of genes in response to hypoxia. ${ }^{15-20} \mathrm{HIF}$ activation results in upregulation of erythropoietin, angiogenic factors, and vasoactive mediators; activation of glycolytic enzymes to produce anaerobic metabolism (with resulting lactate production); and even a mitochondrial hibernation-like phenomenon resulting in decreased oxygen demands. ${ }^{15-24}$ HIFs can also down-regulate other processes in response to hypoxia. ${ }^{15}$ All of these actions are designed to enhance cellular tolerance to hypoxia.

Experimentally, HIFs have been implicated as protective in a number of ischemic models. Examples include the phenomenon of cardiac ischemia preconditioning (which reduces experimental myocardial infarct size), ${ }^{25,26}$ protection from the systemic effects of ischemic colitis, ${ }^{27,28}$ and protection from limb ischemia. ${ }^{29,30}$ HIFs have also been demonstrated to be increased in high altitude dwelling
Tibetans $^{31}$ and to be crucial in fetal development. ${ }^{32}$ Ironically, the angiogenesis properties of HIFs have also been related to accelerated tumor growth. ${ }^{33}$ Recent work has implicated other cellular factors, including endogenous carbon monoxide and hydrogen sulfide, as mediators of intracellular hypoxic protection. ${ }^{5}$

In healthy individuals in hypoxemic environments, these compensatory mechanisms can be quite effective. Classic examples include the ability of humans to live at very high altitudes with a $\mathrm{P}_{\mathrm{aO}_{2}}$ of $\leq 50 \mathrm{~mm} \mathrm{Hg}^{5,34,35}$ and stories of stowaways surviving in airplane landing gear assemblies for many hours at an altitude of 35,000 feet (CNN website, April 21, 2014). Similarly, the near-term fetus has a $\mathrm{P}_{a O_{2}}$ of $<30 \mathrm{~mm} \mathrm{Hg.}{ }^{5,36}$ It is clear that, with proper compensatory mechanisms, mammalian cells can thrive with a $\mathrm{P}_{\mathrm{aO}_{2}}$ lower than the traditional clinical thresholds of 55$60 \mathrm{~mm} \mathrm{Hg}$.

In diseased individuals, many of these compensatory mechanisms may be blunted. Systemic inflammation and organ dysfunction may impair ventilation, create poor $\dot{V} / \dot{Q}$ mismatching, limit cardiac function, disrupt proper control of systemic perfusion distribution, impair tissue oxygen extraction, and limit the $\mathrm{Hb}$ response..$^{8,9}$ Tolerance to low levels of $\mathrm{O}_{2}$ and $\mathrm{P}_{\mathrm{aO}_{2}}$ in disease states is thus likely to be reduced compared with healthy individuals. For example, an otherwise healthy individual in the ICU with low oxygen demands (eg, a hypothermic drowning victim) might be expected to tolerate much lower oxygenation levels than an elderly septic patient with high oxygen demands.

\section{Current and Future Clinical Implications}

Managing hypoxia traditionally involves efforts to improve oxygen delivery and focuses on blood oxygenation $\left(\mathrm{P}_{\mathrm{O}_{2}}\right.$ and $\left.\mathrm{Hb}\right)$ and cardiac output. The relative value of manipulating each of these parameters is given in Table 2.37 Importantly, each of these interventions has consequences. ${ }^{38}$ Improving $\mathrm{P}_{\mathrm{O}_{2}}$ usually involves supplemental oxygen and positive-pressure ventilation, which expose patients to risks of oxygen toxicity and ventilator-induced lung injury. Transfusions expose patients to fluid overload, immunologic risks, and possible transfusion-related lung injuries. Increasing cardiac output exposes patients to risks of fluid overload and excessive adrenergic stimulation. Thus, like so many interventions employed in critical care, improving the physiology of oxygen delivery may not translate into improved outcomes and must always be implemented cautiously.

An alternative way to manipulate tissue oxygenation is to manipulate oxygen consumption. On a global level, this can be done through pain management, fever control, agitation control, neuromuscular blockade, or cooling (eg, therapeutic hypothermia after cardiac arrest). ${ }^{39,40}$ Indeed, 


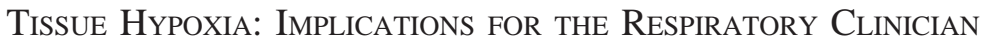

Table 2. Relative Effects of Changes in $\mathrm{P}_{\mathrm{aO}}, \mathrm{Hb}$, and $\dot{\mathrm{Q}}_{\mathrm{T}}$ on $\mathrm{D}_{\mathrm{O}_{2}}$

\begin{tabular}{|c|c|c|c|c|c|c|c|c|c|}
\hline & $\mathrm{F}_{\mathrm{IO}_{2}}$ & $\begin{array}{c}\mathrm{P}_{\mathrm{aO}_{2}} \\
(\mathrm{~mm} \mathrm{Hg})\end{array}$ & $\begin{array}{l}\mathrm{S}_{\mathrm{aO}_{2}} \\
(\%)\end{array}$ & $\begin{array}{l}\mathrm{Hb} \\
(\mathrm{g} / \mathrm{L})\end{array}$ & $\begin{array}{l}\text { Dissolved } \mathrm{O}_{2} \\
(\mathrm{~mL} / \mathrm{L})\end{array}$ & $\begin{array}{c}\mathrm{C}_{\mathrm{aO}_{2}} \\
(\mathrm{~mL} / \mathrm{L})\end{array}$ & $\begin{array}{c}\dot{\mathrm{Q}}_{\mathrm{T}} \\
(\mathrm{L} / \mathrm{min})\end{array}$ & $\begin{array}{c}\mathrm{D}_{\mathrm{O}_{2}} \\
(\mathrm{~mL} / \mathrm{min})\end{array}$ & $\begin{array}{c}\mathrm{D}_{\mathrm{O}_{2}} \\
\text { (\% change)* }\end{array}$ \\
\hline Normal $\dagger$ & 0.21 & 97.5 & 96 & 130 & 3.0 & 170 & 5.3 & 900 & 0 \\
\hline Patient $\neq$ & 0.21 & 45.0 & 75 & 70 & 1.4 & 72 & 4.0 & 288 & -68 \\
\hline$\uparrow \mathrm{F}_{\mathrm{IO}_{2}}$ & 0.35 & 67.5 & 92 & 70 & 2.1 & 88 & 4.0 & 352 & +22 \\
\hline$\uparrow \uparrow \mathrm{F}_{\mathrm{IO}_{2}}$ & 0.60 & 123.8 & 98 & 70 & 3.8 & 96 & 4.0 & 384 & +9 \\
\hline$\uparrow \mathrm{Hb}$ & 0.60 & 123.8 & 98 & 105 & 3.8 & 142 & 4.0 & 568 & +48 \\
\hline$\uparrow \dot{\mathrm{Q}}_{\mathrm{T}}$ & 0.60 & 123.8 & 98 & 105 & 3.8 & 142 & 6.0 & 852 & +50 \\
\hline \multicolumn{10}{|c|}{ 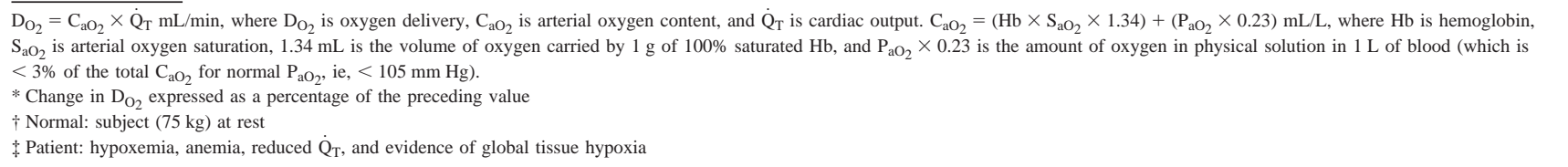 } \\
\hline
\end{tabular}

the ability to survive at 35,000 feet in the wheel wells of a commercial aircraft as noted above was likely associated with hypothermia-induced hibernation of tissues. Each of these, to varying degrees, can lower $\mathrm{O}_{2}$ demands in specific tissue beds to improve regional tissue oxygenation. However, these manipulations can have their own toxicities. For example, narcotics and anxiolytics can prolong the need for mechanical ventilation, ${ }^{41}$ and neuromuscular blockade can lead to respiratory muscle disuse atrophy. ${ }^{42}$ Whether hypothermia produces long-term injury is unknown.

As we move into the future, focus is needed in 2 areas. First, more direct assessments of regional hypoxia and an understanding of threshold levels for hypoxic injury in different regions are required. ${ }^{43}$ This will allow us to better balance tradeoffs associated with conventional therapies. Second, future therapies need to address both regional manipulations of oxygen delivery and the development of strategies building upon the powerful compensatory mechanisms already present in cells.

Regarding assessments, the traditional way to quantify tissue hypoxia is to simplify and measure only global hypoxemia, oxygen delivery, and oxygen extraction. Commonly recommended therapeutic targets are a $\mathrm{P}_{\mathrm{aO}_{2}}$ of $>55 \mathrm{~mm} \mathrm{Hg}, \mathrm{Hb}$ levels of at least $70 \mathrm{~g} / \mathrm{L}$ (but perhaps as high as 90-100 g/L in high $\mathrm{O}_{2}$ demand states), and cardiac indices (cardiac output referenced to body surface area) of $>2 \mathrm{~L} / \mathrm{min} / \mathrm{m}^{2} \cdot 38$

However, oxygen utilization monitoring might offer more in-depth assessments of overall body oxygenation status than simple oxygen delivery. Using this approach, oxygen delivery could be deemed adequate if total body oxygen consumption was adequate $(250 \mathrm{~mL} / \mathrm{min}$ in a normal metabolic state: perhaps higher in sepsis, perhaps lower in the presence of paralytics). Indeed, a number of clinical studies in the last 2 decades argued that oxygen delivery should be increased until oxygen consumption is no longer increased. ${ }^{44}$ However, because assessments of oxygen delivery and oxygen consumption utilize common variables (cardiac output and $\mathrm{P}_{\mathrm{aO}}$ content), the use of simply the mixed venous $\mathrm{P}_{\mathrm{O}_{2}}$ or mixed venous oxyhemoglobin saturation has been proposed as a more focused assessment of tissue oxygenation. ${ }^{45,46}$ With this approach, a mixed venous $\mathrm{P}_{\mathrm{O}_{2}}$ of $>40 \mathrm{~mm} \mathrm{Hg}$ or mixed venous oxyhemoglobin saturation of $>70 \%$ (so-called goal-directed therapy) ${ }^{47}$ might suggest the presence of adequate oxygen delivery. Importantly, these approaches assume that oxygen extraction capabilities are near normal, something that might not be present in a severe systemic inflammatory response state. Serum lactate has also been suggested as a monitor for global adequacy of oxygen delivery. ${ }^{48}$

It is clear from the discussion above that these global parameters are insensitive and nonspecific indicators of safe oxygenation at the regional tissue level. Thus, efforts to normalize these global values may force excessive use of potentially harmful support strategies. ${ }^{38}$ However, current attempts to assess regional hypoxia are largely indirect through monitoring of specific organ functions. Examples include monitoring heart function (contractility, dysrhythmias), renal function (creatinine), liver function (liver metabolic properties and enzymes), and central nervous system function (mental status or seizures). If we are ever going to be comfortable with global permissive hypoxemia (ie, allowing a $\mathrm{P}_{\mathrm{aO}_{2}}$ of $<55 \mathrm{~mm} \mathrm{Hg}$ ), regional assessments are going to be critical to guide therapy. ${ }^{49-53}$

Two organs for which direct venous or tissue $\mathrm{P}_{\mathrm{O}_{2}}$ values are available are the brain and the intestine. The brain is a logical monitoring site, as it is the organ that is most sensitive to hypoxia. ${ }^{5}$ Both animal and human studies suggest that an intracellular $\mathrm{P}_{\mathrm{O}_{2}}$ in brain tissue of $<10-$ $15 \mathrm{~mm} \mathrm{Hg}$ is injurious. ${ }^{54}$ Brain injury is also associated with oxyhemoglobin saturation of $<50-54 \%$ in blood sampled in the jugular venous system. ${ }^{55}$ External probes placed on the forehead to measure oxidative state using 


\section{Tissue HyPOXIA: IMPLiCATIONS FOR THE ResPiRATORy Clinician}

near-infrared technology are theoretically attractive but subject to artifacts from muscle metabolism on the scalp..$^{56}$

The intestine is also an attractive site to monitor, as regional hypoxia there results in translocation of intestinal bacteria into blood. This conceptually feeds systemic inflammation and multiple organ failure. ${ }^{57}$ Moreover, if intestinal oxygenation is thought to be adequate, other organs such as the brain are also likely to be adequate. Currently available monitors utilize intestinal luminal $\mathrm{pH}$ $\left(\mathrm{P}_{\mathrm{CO}_{2}}\right)$ sensors to determine oxygenation adequacy. ${ }^{57}$

In future therapies, we will need a better understanding of how regional blood flow is modulated and how oxygen is extracted and utilized both under normal conditions and in disease states. We also need a better understanding of the remarkable compensatory mechanisms for hypoxia that exist and develop ways to harness them. Examples of future therapies might include $\mathrm{Hb}$ manipulations for more targeted blood flow and exploitation of HIF properties to better protect the hypoxic cell. The next decade should provide exciting new ways to support hypoxic patients.

\section{Summary}

Hypoxia is the presence of lower than normal oxygen content and pressure in the cell. Causes of hypoxia include hypoxemia (low blood oxygen content and pressure), impaired oxygen delivery, and impaired cellular oxygen uptake/utilization. Many compensatory mechanisms exist at the global, regional, and cellular levels to allow cells to function in a hypoxic environment. Clinical management of tissue hypoxia usually focuses on global hypoxemia and oxygen delivery. In the future, the clinical focus needs to change to assessing and managing regional hypoxia in critical organs to avoid unnecessary and potential toxic global strategies. We also need to focus on understanding and better harnessing the body's own adaptive mechanisms to hypoxia.

\section{REFERENCES}

1. Murray JF. Gas exchange and oxygen transport. In: Murray JF, editor. The normal lung, 2nd edition. Philadelphia: WB Saunders; 1986;183-210.

2. West JB. Pulmonary pathophysiology - the essentials, 7th edition. Baltimore: Lippincott Williams \&Wilkins; 2007.

3. Finch CA, Lenfant C. Oxygen transport in man. N Engl J Med 1972;286(8):407-415.

4. Leach RM, Treacher DF. Oxygen transport: 2: tissue hypoxia. BMJ 1998;317(7169):1370-1373.

5. Martin DS, Khosravi M, Grocott M, Mythen MG. Concepts in hypoxia reborn. Crit Care 2010;14(4):315.

6. Comroe JH, Forster RE, Dubois AB, Briscoe WA, Carlsen E. The lung, clinical physiology and pulmonary function tests, 2nd edition. Chicago: Year Book Medical Publishers; 1977.

7. Mairbäurl H, Weber RE. Oxygen transport by hemoglobin. Compr Physiol 2012;2(2):1463-1489.
8. Ruokonen E, Takala J, Kari A, Saxén H, Mertsola J, Hansen EJ. Regional blood flow and oxygen transport in septic shock. Crit Care Med 1993;21(9):1296-1303.

9. De Backer D, Creteur J, Preiser JC, Dubois MJ, Vincent JL. Microvascular blood flow is altered in patients with sepsis. Am J Respir Crit Care Med 2002;166(1):98-104.

10. Sonveaux P, Lobysheva II, Feron O, McMahon TJ. Transport and peripheral bioactivities of nitrogen oxides carried by red blood cell hemoglobin: role in oxygen delivery. Physiology 2007;22:97-112.

11. Gaston B, Singel D, Doctor A, Stamler JS. S-nitrosothiol signaling in respiratory biology. Am J Respir Crit Care Med 2006;173(11): 1186-1193.

12. Hill BG. Recent advances in mitochondrial research. Circ Res 2013; 113(12):e107-e110

13. Mik EG. Measuring mitochondrial oxygen tension: from basic principles to application in humans. Anesth Analg 2013;117(4):834-846.

14. Hamel J. A review of acute cyanide poisoning with a treatment update. Crit Care Nurse 2011;31(1):72-81.

15. Schumacker PT. Hypoxia-inducible factor-1 (HIF-1). Crit Care Med 2005;33(12 Suppl):S423-S425.

16. Semenza GL. Hypoxia inducible factors in physiology and medicine. Cell 2012;148(3):399-408.

17. Chandel NS, Maltepe E, Goldwasser E, Mathieu CE, Simon MC, Schumacker PT. Mitochondrial reactive oxygen species trigger hypoxia-induced transcription. Proc Natl Acad Sci USA 1998;95(20): 11715-11720.

18. Formenti F, Constantin-Teodosiu D, Emmanuel Y, Cheeseman J, Dorrington KL, Edwards LM, et al. Regulation of human metabolism by hypoxia-inducible factor. Proc Natl Acad Sci USA 2010; 107(28):12722-12727.

19. Kaelin WG Jr, Ratcliffe PJ. Oxygen sensing by metazoans: the central role of HIF hydroxylase pathway. Mol Cell 2008;30(4):393-402.

20. Majmundar AJ, Wong WJ, Simon MC. Hypoxia-inducible factors and the response to hypoxic stress. Mol Cell 2010;40(2):294-309.

21. Yoon D, Ponka P, Prchal JT. Hypoxia and hematopoiesis. Am J Physiol Cell Physiol 2011;300(6):C1215-C1222.

22. Dehne N, Fuhrmann D, Brüne B. Hypoxia-inducible factor (HIF) in hormone signaling during health and disease. Cardiovasc Hematol Agents Med Chem 2013;11(2):125-135.

23. Fukuda R, Zhang H, Kim JW, Shimoda L, Dang CV, Semenza GL. HIF-1 regulates cytochrome oxidase subunits to optimize efficiency of respiration in hypoxic cells. Cell 2007;129(1):111-122.

24. Papandreou I, Cairns RA, Fontana L, Lim AL, Denko NC. HIF-1 mediates adaptation to hypoxia by actively downregulating mitochondrial oxygen consumption. Cell Metab 2006;3(3):187-197.

25. Resar JR, Roguin A, Voner J, Nasir K, Hennebry TA, Miller JM, et al. Hypoxia-inducible factor $1 \alpha$ polymorphism and coronary collaterals in patients with ischemic heart disease. Chest 2005;128(2): 787-791.

26. Eckle T, Köhler D, Lehmann R, El Kasmi K, Eltzschig HK. Hypoxia-inducible factor- 1 is central to cardioprotection: a new paradigm for ischemic pre-conditioning. Circulation 2008;118(2): 166-175.

27. Karhausen J, Furuta GT, Tomaszewski JE, Johnson RS, Colgan SP, Haase VH. Epithelial hypoxia-inducible factor-1 is protective in murine experimental colitis. J Clin Invest 2004;114(8):1098-1106.

28. Hirota, SA, Fines $\mathrm{K}, \mathrm{Ng} \mathrm{J}$, Traboulsi D, Lee J, Ihara E, et al. Hypoxia-inducible factor signaling provides protection in Clostridium difficile-induced intestinal injury. Gastroenterology 2010;139(1): 259.e3-269.e3.

29. Bosch-Marcé M, Okuyama H, Wesley JB, Sarkar K, Kimura H, Liu $\mathrm{YV}$, et al. Effects of aging and hypoxia-inducible factor-1 activity on angiogenic cell mobilization and recovery of perfusion after limb ischemia. Circ Res 2007;101(12):1310-1318. 


\section{Tissue Hypoxia: Implications fOR the Respiratory Clinician}

30. Sarkar K, Fox-Talbot K, Steenbergen C, Bosch-Marcé M, Semenza GL. Adenoviral transfer of HIF- $1 \alpha$ enhances vascular responses to critical limb ischemia in diabetic mice. Proc Natl Acad Sci USA 2009;106(44):18769-18774.

31. Simonson TS, Yang Y, Huff CD, Yun H, Qin G, Witherspoon DJ, et al. Genetic evidence for high-altitude adaptation in Tibet. Science 2010;329(5987):72-75.

32. Dunwoodie SL. The role of hypoxia in the development of the human embryo. Dev Cell 2009;17(6):755-773.

33. Liao D, Johnson RS. Hypoxia: a key regulator of angiogenesis in cancer. Cancer Metastasis Rev 2007;26(2):281-290.

34. Martin D, Windsor J. From mountain to bedside: understanding the clinical relevance of human acclimatization to high-altitude hypoxia. Postgrad Med J 2008;84(998):622-627.

35. Beall CM. Andean, Tibetan, and Ethiopian patterns of adaptation to high-altitude hypoxia. Integr Comp Biol 2006;46(1):18-24.

36. Richardson BS, Bocking AD. Metabolic and circulatory adaptations to chronic hypoxia in the fetus. Comp Biochem Physiol A Mol Integr Physiol 1998;119(3):717-723.

37. Leach RM, Treacher DF. The pulmonary physician in critical care 2 : oxygen delivery and consumption in the critically ill. Thorax 2002; 57(2):170-177.

38. MacIntyre NR. Supporting oxygenation in acute respiratory failure. Respir Care 2013;58(1):142-150

39. Papazian L, Forel JM, Gacouin A, Penot-Ragon C, Perrin G, Loundou A, et al. Neuromuscular blockers in early acute respiratory distress syndrome. N Engl J Med 2010;363(12):1107-1116.

40. Manthous CA, Hall JB, Olson D, Singh M, Chatila W, Pohlman A, et al. Effect of cooling on oxygen consumption in febrile critically ill patients. Am J Respir Crit Care Med 1995;151(1):10-14.

41. Hooper MH, Girard TD. Sedation and weaning from mechanical ventilation: linking spontaneous awakening trials and spontaneous breathing trials to improve patient outcomes. Anesthesiol Clin 2011; 29(4):651-661.

42. Vassilakopoulos T, Petrof BJ. Ventilator induced diaphragmatic dysfunction. Am J Respir Crit Care Med 2004;169(3):336-341.

43. Wan JJ, Cohen MJ, Rosenthal G, Haitsma IK, Morabito DJ, Derugin $\mathrm{N}$, et al. Refining resuscitation strategies using tissue oxygen and perfusion monitoring in critical organ beds. J Trauma 2009;66(2): 353-357.
44. Vincent JL, De Backer D. Oxygen transport-the oxygen delivery controversy. Intensive Care Med 2004;30(11):1990-1996.

45. Walley KR. Use of central venous oxygen saturation to guide therapy. Am J Respir Crit Care Med 2011;184(5):514-520.

46. van Beest P, Wietasch G, Scheeren T, Spronk P, Kuiper M. Clinical review: use of venous oxygen saturations as a goal: a yet unfinished puzzle. Crit Care 2011;15(5):232-240.

47. Otero RM, Nguyen HB, Huang DT, Gaieski DF, Goyal M, Gunnerson KJ, et al. Early goal-directed therapy in severe sepsis and septic shock revisited: concepts, controversies, and contemporary findings. Chest 2006;130(5):1579-1595.

48. Bakker J, Coffernils M, Leon M, Gris P, Vincent JL. Blood lactate levels are superior to oxygen-derived variables in predicting outcome in human septic shock. Chest 1991;99(4):956-962.

49. Cheifetz IM, Hamel DS. Is permissive hypoxemia a beneficial strategy for pediatric acute lung injury? Respir Care Clin N Am 2006; 12(3):359-369.

50. Abdelsalam M, Cheifetz IM. Goal-directed therapy for severely hypoxic patients with acute respiratory distress syndrome: permissive hypoxemia. Respir Care 2010;55(11):1483-1490.

51. Abdelsalam M. Permissive hypoxemia: is it time to change our approach? Chest 2006;129(1):210-211.

52. Third European Consensus Conference in Intensive Care Medicine. Tissue hypoxia: how to detect, how to correct, how to prevent. Am J Respir Crit Care Med 1996;154(5):1573-1578.

53. Carreau A, El Hafny-Rahbi B, Matejuk A, Grillon C, Kieda C. Why is the partial pressure of human tissues a critical parameter? Small molecules and hypoxia. J Cell Mol Med 2011;15(6):1239-1253.

54. Purins K, Enblad P, Wiklund L, Lewén A. Brain tissue oxygenation and cerebral perfusion pressure thresholds of ischemia in standardized pig brain death model. Neurocrit Care 2012;16(3):462-469.

55. Ponce LL, Navarro JC, Robertson CS. Advanced bedside neuromonitoring. In: Vincent JL, Abraham E, Moore FA, Kochanek PM, Fink MP, editors. Textbook of critical care, 6th edition. Philadelphia: Elsevier; 2011;146-152.

56. Eda H. Near-infrared spectroscopy in studies of brain oxygenation. Curr Pharm Biotechnol 2013;14(2):167-171.

57. Gutierrez G, Palizas F, Doglio G, Wainsztein N, Gallesio A, Pacin J, et al. Gastric intramucosal $\mathrm{pH}$ as a therapeutic index of tissue oxygenation in critically ill patients. Lancet 1992;339(8787):195-199. 